\title{
The Demand for Simple-sum and Divisia Monetary Aggregates for Pakistan: A Cointegration Approach
}

\author{
Syed MUHAMmad TARIQ and KENT MATTHEWS
}

\begin{abstract}
Financial liberalisation and the advance of financial innovation in a number of developed economies has been blamed for the break-down in the demand for money based on simple sum measures. This break-down has prompted research into Divisia measures of the demand for money. Like many developing countries, Pakistan is going through a period of financial deregulation which goes hand in hand with financial innovation due to increased competition in the banking industry. This paper employs the methodology of cointegration to compare simple-sum and Divisia level estimates of the demand for money for Pakistan for the period 1974Q4 to 1992Q4. Simple sum measures of M1 and M2 were compared with Divisia versions. The paper reports little evidence in support of the superiority of the Divisia monetary aggregates. Both types of measure produce a stable demand for money and perform satisfactorily in post-sample stability tests, although the Divisia measure appears to perform marginally better on conventional statistical criteria. However, our conclusions have to be qualified by the limitations of the data and the knowledge that the period of financial innovation and deregulation has been relatively recent. The policy significance of the results suggests that currently there is no advantage from switching from simple-sum to Divisia aggregates at the existing level of official aggregation as the proper indicator of monetary policy. However, if financial deregulation and innovation continues at the current pace, the Divisia aggregates may in future prove to be the better indicator.
\end{abstract}

\section{INTRODUCTION}

The stability of the money demand function is one of the most important issues in the theory and application of macroeconomic policy. A stable money demand function means that the quantity of money is predictably related to a small set of key economic variables linking money to the real sector of the economy. Like many developing countries, Pakistan is going through a period of financial deregulation which goes hand in hand with financial innovation due to increased competition in the banking industry. In such a situation, simple-sum monetary aggregates may not be the appropriate indicators of the conduct of monetary policy.

Syed Muhammad Tariq works for the State Bank of Pakistan, Karachi. Kent Matthews is based at the Cardiff Business School, University of Wales College of Cardiff, Cardiff, Wales, U.K.

Authors' Note: We are thankful to an anonymous referee of this Review for suggesting improvements in an earlier draft of this paper. However, the responsibility for any errors remaining rests upon us. Further, the views expressed in this paper are personal views of the authors and do not in any way represent the views of the organisations where they work. 
This paper is concerned with the estimation of the demand for monetary aggregates based on simple-sum and Divisia aggregation procedures. We use the theory of cointegration developed by Engle and Granger (1987) and Johansen (1988). Using Johansen's procedure, we first determine a long-run cointegrating relationship among the variables of interest. Based on this relationship, we will try to find a stable dynamic specification of the money demand function for both simple-sum and Divisia monetary aggregates.

The paper is organised as follows. In Section 2, we discuss the composition of official monetary aggregates in Pakistan. A brief survey of empirical studies on money demand in Pakistan is presented in Section 3. In Section 4, a theoretical money demand function based on the theory of transaction demand for money is specified. In Section 5, we briefly discuss the concept of partial system and weak exogeneity. Construction of data and its sources is explained in Section 6. In Section 7 , we report and discuss the results of cointegration analysis to determine the longrun demand for money function. Finally, the dynamic demand for money function is estimated in Section 8.

\section{COMPOSITION OF MONETARY AGGREGATES IN PAKISTAN}

In Pakistan, the concept of 'money supply' was originally used to denote the public's total purchasing power which constitutes the immediate demand for goods and services. Monetary aggregates have mainly been defined in terms of the institutions whose liabilities are included. Thus, money supply, consisting of liquid assets held by the public, included: (a) currency in circulation outside the banking system; (b) demand deposits with the scheduled banks (excluding inter-bank deposits, deposits of central and provincial governments, and foreign constituents); and (c) other deposits with the State Bank of Pakistan [SBP] (excluding the counterpart fund, deposits of foreign central banks, foreign governments, and deposit money banks). The distinction between money and near money became blurred in the late sixties, because of the increasing use of 'near money' deposits, and their increased monetisation. Scheduled banks permitted the depositors to withdraw time deposits of some categories and saving accounts by cheques, and those deposits were being freely used for current transactions. Hence, in January 1969, a broader concept of money (M2) was adopted, which, in addition to M1, also included the time deposits with the scheduled banks (excluding inter-bank deposits, deposits of central and provincial governments, and foreign constituents), post office saving bank deposits, and deposits of non-scheduled and co-operative banks with the SBP. It is now accepted that M2 is the most relevant monetary aggregate used for the purposes of monetary analysis in Pakistan. However, these definitions have been amended and supplemented on a number of occasions, reflecting both developments in the financial system and in policy. In order to make the computation of M2 comparable with the International Monetary Fund (IMF) computation, post office saving bank 
deposits and deposits of non-scheduled and co-operative banks with the SBP were excluded from M2 in June, 1980. On 23rd February 1991, resident Pakistanis were allowed to open Resident Foreign Currency Deposit Accounts and these deposits have been included as part of monetary assets instead of as a foreign liability. The official aggregates (M1 and M2) are obtained by the simple-summation procedure, i.e., by adding the individual financial assets included in a particular aggregate. These two monetary aggregates are currently subject to close scrutiny by the authorities. $^{1}$

\section{SURVEY OF EMPIRICAL STUDIES ON THE DEMAND FOR MONEY IN PAKISTAN}

Monetary policy in Pakistan is formulated to assist the realisation of the targeted growth rate together with price stability and a viable balance of payments. In order to achieve these objectives, the monetary authorities regulate the volume and cost of the broader monetary aggregate, M2. Because of its central importance for the conduct of monetary policy, the demand for money is probably one of the most heavily researched areas of applied econometrics, both in developed countries and, increasingly, in developing countries. The demand for money in Pakistan has been the subject of extensive study. ${ }^{2}$ There is little empirical difference whether measured or permanent income is used as the scale variable [Mangla (1979)]. While some researchers have argued that inflation is the appropriate opportunity cost of money, ${ }^{3}$ others argue that the return on deposits and the inter-bank call money rate did have a significant impact on money holding in Pakistan. ${ }^{4}$

The issue of the stability of the money demand function has, however, received less attention. Ahmad and Khan (1990) tested the stability of the money demand function for the period 1959-60 to 1986-87 using a robust technique that permits parameters to vary over time, and concluded that the money demand function corresponding to both M1 and M2 was unstable after 1980-81. In contrast, Sassanpour and Moinuddin (1993), using the data from 1973-74 to 1991-92, conducted various stability tests and found the money demand function to be stable.

${ }^{1}$ The Economic Adviser’s Wing, Ministry of Finance, Government of Pakistan, has quantified a further broad measure of money, M3, by adding outstanding deposits of some other institutions not covered under M2. These include outstanding deposits of the National Development Finance Corporation (NDFC) Bearer Certificates, deposits of the National Savings Schemes, and deposits of the Federal Bank for Co-operatives (FBC). However, it may be pointed out that deposits of the FBCs as a schedule bank are already included in M2. Economic Adviser's Wing is apparently double-counting the deposits of the FBCs in their broad monetary aggregate, M3.

${ }^{2}$ See for example, Akhtar (1974); Abe et al. (1975); Mangla (1979); Khan (1980, 1981, 1982, 1982a, 1982b, 1982c, 1994); Nisar and Aslam (1983); Khan and Raza (1989); Ahmad and Khan (1990) and Sassanpour and Moinuddin (1993).

${ }^{3}$ Aghevli et al. (1979); Khan (1980) and Wong (1977).

${ }^{4}$ Notably Khan (1980, 1982, 1982a, 1982b), but also Mangla (1979). 
A further issue is that, except for Khan and Raza (1989), all the studies have used annual data. This limitation was caused by the unavailability of quarterly data on the scale variable, i.e., GNP/GDP. Although, the results of these studies have provided useful insights, Goldfeld (1973), has argued that the results based on quarterly data are more useful for the conduct of monetary policy since policy decisions are made within fairly short intervals. Estimation of a quarterly money demand function will also enable us to evaluate short-run variations in money demand behaviour. Additionally, most of the studies of the demand for money function are biased by the inclusion of the pre-1972 period, before the break-up of Pakistan in 1971, into two separate independent countries, viz., Pakistan and Bangladesh. It will be more meaningful if we could model a stable money demand function using the post-1972 data for policy considerations. Furthermore, the financial system in Pakistan has undergone a fundamental change during the 1980s. It follows that a Divisia-based demand for money may be more appropriate than one based on a simple-sum.

\section{THEORETICAL MONEY DEMAND FUNCTION}

The existence of an identifiable and stable demand function is an important requirement for any monetary aggregate that serves as an intermediate target. The general functional form is:

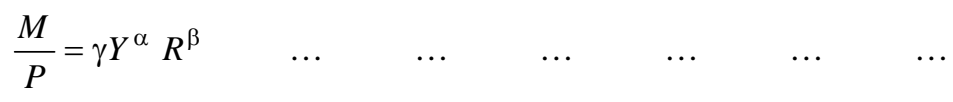

where ' $M$ ' is money, ' $P$ ' is the general price level, ' $Y$ ' is real income, ' $R$ ' is the nominal interest rate on an alternative asset, and $\gamma, \alpha, \beta$, are the parameters to be estimated.

For our simple-sum monetary aggregates, we replace the nominal interest rate on the alternative asset (the opportunity cost variable) with the corresponding differential between the interest rate on an alternative asset and the own rate of return on the monetary aggregate, because some of the components included in the monetary aggregate are also interest-bearing. For the Divisia monetary aggregates, we replace the level of nominal interest rates in the standard equation with a user cost measure which is also based on interest rate differentials. The measures we use are the corresponding real price dual of Divisia aggregates. In keeping with other studies, we have used real GNP as the relevant scale variable.

We estimate a dynamic money demand equation using the methodology of cointegration. All the variables are in logs, and long-run price homogeneity of the money demand function is imposed. This enables us to estimate the real money demand function for Divisia and simple-sum aggregates. The aim is to establish the 
existence of at least one "cointegrating vector" which is then used as the foundation for a dynamic adjustment model, in which the variables are adjusting to disequilibria in money balances (simple-sum or Divisia). The data sample is restricted to the period 1974Q4-92Q4.

\section{PARTIAL SYSTEM AND WEAK EXOGENEITY}

The cointegrating vectors are obtained from the reduced form of a system where all the variables are assumed to be jointly endogenous. Consequently, they cannot be interpreted as representing structural equations, and in general there is no way to go from the reduced form back to the structure. However, Dickey et al. (1991) have suggested that the cointegrating vectors might be thought of as arising from a constraint that an economic structure imposes on the long-run relationship among the jointly endogenous variables. Johansen and Juselius (1990) also suggested that the cointegrating vectors can be interpreted economically by determining the regression direction through the significance of the cointegration weights. In the context of Johansen's approach, zero restrictions on the adjustment coefficients associated with the error-correction components of the VAR have been interpreted by Johansen and Juselius (1992); Hendry and Mizon (1993) and Ericsson et al. (1990) as tests for weak exogeneity of the cointegrating relations.

A partial system as a conditional model can be defined under the vector autoregressive formulation where the properties of the conditioning variables are well-defined. Consider the following error correction model under the hypothesis of cointegration:

$$
\Delta X_{t}=\mu+\Pi X_{t-1}+\sum_{i=1}^{k-1} \Gamma_{i} \Delta X_{t-1}+\varepsilon_{t} ; t=1, \ldots, T ;
$$

where, $X_{t}=\left(Y_{t}, Z_{t}\right)^{\prime}, \Pi=\sum_{i=1}^{k} \Pi_{i}-1, \Gamma_{i}=-\sum_{j=i+1}^{k} \Pi_{j}, i=1, \ldots ., k-1$;

The above model can be decomposed into the conditional model for ' $Y_{t}$ ' given ' $Z_{t}^{\prime}$ '

$$
\Delta Y_{t}=\mu_{y}-\omega \mu_{z}+\omega \Delta Z_{t}+\left(\alpha_{y}-\omega \alpha_{z}\right) \beta^{\prime} X_{t-1}+\sum_{i=1}^{k-1}\left(\Gamma_{y t}-\omega \Gamma_{z t}\right) \Delta X_{t-i}+\varepsilon_{y t}-\omega \varepsilon_{z t}
$$

and the marginal model of $Z_{t}$

$$
\Delta Z_{t}=\mu_{z}+\alpha_{z} \beta^{\prime} X_{t-1}+\sum_{i=1}^{k-1} \Gamma_{z t} \Delta X_{t-i}+\varepsilon_{z t}
$$

where $\omega=\Omega_{y z} \Omega_{z z}{ }^{-1}$ 
Both the conditional and marginal models include the cointegrating relations $\beta^{\prime} X_{t-1}$ and the conditional model has new adjustment coefficients $\left(\alpha_{y}-\omega \alpha_{z}\right)$ depending on the covariance matrix of the errors and all the adjustment coefficients. Since the parameters of the marginal and conditional systems are interrelated, full system analysis is needed to draw efficient inference about the parameters. However, if ' $Z_{t}$ ' is weakly exogenous for ' $\alpha$ ' and ' $\beta$ ' [Engle et al. (1983)], the analysis of the partial model is efficient. Thus, if the parameters of interest in the above model are all the parameters of ' $\beta$ ', then weak exogeneity of ' $Z_{t}^{\prime}$ ' with respect to ' $\beta$ ' is equivalent to the condition that $\alpha_{z}=0$ and the conditional and marginal models reduce to

$$
\Delta Y_{t}=\mu_{y}-\omega \mu_{z}+\omega \Delta Z_{t}+\alpha_{y} \beta^{\prime} X_{t-1}+\sum_{i=1}^{k-1}\left(\Gamma_{y i}-\omega \Gamma_{z i}\right) \Delta X_{t-i}+\varepsilon_{y t}-\omega \varepsilon_{z t}
$$

and

$$
\Delta Z_{t}=\mu_{z}+\sum_{i=1}^{k-1} \Gamma_{z t} \Delta X_{t-i}+\varepsilon_{z t}
$$

The ' $\beta$ ' and the remaining adjustment coefficients ' $\alpha$ ' enter only in the partial model and the properties of the Gaussian distribution show that the parameters in the partial and marginal models are variation-free [see Johansen (1992) and Boswijk (1990)]. The marginal model, however, includes the lagged differences of all the variables included in the VAR, i.e., $\Delta Z_{t-i}$ as well as $\Delta Y_{t-i}$. If the coefficients of $\Delta Y_{t-i}$ are also zero, i.e., ' $Y_{t}^{\prime}$ ' does not Granger cause ' $Z_{t}$ ', then ' $Z_{t}$ ' is said to be strongly exogenous for ' $\beta$ '. Thus weak exogeneity implies that $\Delta Z_{t}$ does not react to disequilibrium errors but may still react to lagged changes of ' $Y_{t}^{\prime}$ ' and strong exogeneity means that $\Delta Z_{t}$ does not react to changes or levels of ' $Y_{t}$ '.

The hypothesis of weak exogeneity for the long-run parameters can thus be formulated as a parametric restriction on the adjustment coefficients.

\section{DATA}

Official simple-sum monetary aggregates are obtained by the procedure of simple summation of all the component monetary assets which are to be included in a particular aggregate. The measure of narrow money is difficult to define in the case of Pakistan as the boundary between transferable and non-transferable deposits is not very clear. Current and call deposits of scheduled banks are in the nature of demand deposits while fixed deposits are exclusively time deposits. However, savings accounts provide partial chequeing facilities with limitations on the number of cheques that can be drawn and the amounts involved. In addition, the amount that could be transferable by cheque is estimated by reporting banks as a percentage of 
the total savings accounts and is included as part of demand deposits. The actual break-up of saving deposits into transferable and non-transferable components and different percentages for each bank has made it difficult to define money and quasimoney separately on a quarterly basis. It follows that, the broad monetary aggregate (M2) is more relevant for our study. Since saving deposits at scheduled banks are now chequable deposits, we have included the total saving deposits in the narrow measure of money (M1). The SBP adjusts the demand and time deposits of scheduled banks by deducting the inter-bank deposits, deposits of the federal and provincial Governments, and deposits of the foreign constituents before including them in the monetary aggregates. In order to make the Divisia monetary aggregates comparable with the simple-sum, we have also deducted the inter-bank deposits, deposits of the federal and provincial Governments, and deposits of foreign constituents from the total scheduled banks' deposits.

Corresponding to simple-sum monetary aggregates, two Divisia ${ }^{5}$ monetary aggregates (DMI and DM2) have been constructed. Divisia monetary aggregate DM1 includes currency in circulation, other deposits with the SBP, current deposits, call deposits, other deposits, and saving deposits of Scheduled Banks. The broader Divisia monetary aggregate DM2 includes all the financial assets included in DM1 plus total fixed deposits of scheduled banks. Both price and quantity data are used to construct the Divisia monetary aggregates and are obtained from the various publications of the SBP.

The data on own rates of return on these component monetary assets are available as the weighted average rate of return on a quarterly basis and are collected from the various issues of the SBP Annual Report and Monthly Bulletin. Until March 1981, this data are readily available, but from then onward the calculation of own rates of return on component monetary assets became complicated. This was due to the fact that separate interest-free counters started operating in all the nationalised commercial banks and one foreign bank as from 1st January, 1981. These profit and loss-sharing (PLS) ${ }^{6}$ accounts operated side by side with the interestbased deposits till June, 1985 when all the deposits were converted to PLS-based deposits except deposits of foreign constituents and non-matured fixed-term

${ }^{5}$ Following Barnett and Spindt (1979); Barnett (1980); Barnett et al. (1984), Divisia monetary quantity index DM1 and DM2 are constructed using the formula:

$$
\ln D M_{t}-\ln D M_{t-1}=\sum_{i} w_{i t}\left(\operatorname{lnm}_{i t}-\operatorname{lnm}_{i t-1}\right)
$$

where, $D_{M t}$ is the Divisia quantity monetary aggregate at time $t ; m_{i t}$ is the holding of asset $i$ at time $t ; w_{i t}=$ $\frac{1}{2}\left(S_{i t}+S_{i t-1}\right) ; s_{i t}=p_{i t} m_{i t} / \sum_{i}\left(p_{i t} m_{i t}\right)$; and $p_{i t}$ is the user cost (rental price) of asset $i$ at time $t$.

${ }^{6}$ Under PLS banking, in Pakistan, each commercial bank declares its own profit rate on its PLS deposits and is required to declare rates of profit on various types of its PLS deposits on a half-yearly basis ending 30th June and 31st December each year after obtaining clearance from the State Bank. While distributing non-interest income, certain weights, specified and advised by the SBP to the Banks, are applied to PLS deposits, PLS borrowings, and equity of the individual bank. 
deposits. Commercial banks are not permitted to pay interest on current deposits (CD) and other deposits (OD) whether they are PLS-based or Interest-based. The Statistics Department of the State Bank of Pakistan (SBP) computes the weighted average rate of return on PLS deposits from the quarterly returns of scheduled banks on half-yearly basis, i.e., end-June and end-December. Though, the PLS rates of return had been compiled since June, 1982, the SBP only recently (December 1992) started publishing them in its various publications. We have obtained these rates from the Statistics Department of the SBP. Since PLS rates are available on halfyearly basis, we have used the rates for June and December as a proxy for the intervening quarters, i.e., March and September. These PLS rates, together with the rates on interest-based deposits, were then used to calculate the rates of return on both Interest-based and PLS-based deposits combined. The opportunity cost variable is derived for each aggregate by taking the differential of interest rate on alternative assets (the rate of return on government saving scheme) and the own rate of return of that particular monetary aggregate. The own rate of return on monetary aggregates M2 and M1 is defined as a weighted average of the rates of return of component assets included in the particular aggregate, i.e.,

$$
O r_{i}=\sum w_{i t} r_{i t}
$$

where $r_{i}=$ rate of return on each component, and $w_{i}$ the corresponding share of each component in the monetary aggregate.

Theoretically, the benchmark rate $R_{t}$ is the yield on assets accumulated in order to transfer wealth between multi-period planning horizons rather than to provide liquidity or other monetary services during the current period. We have selected the rate of return on Khas-deposit Certificates/Accounts (KDCs) as the benchmark rate. This saving instrument was one of the many Government saving instruments available in the economy. There was almost no variation in the rate of return, and nominal rate of return on KDCs was revised only on four occasions since its inception. The rate of return on KDCs is uniformly higher than the rate of return on all the monetary components included in the conventional monetary aggregates (M1 and M2), thus ensuring non-negative user costs; though KDCs were discontinued in the first quarter of 1990 and were replaced by special saving certificates (SSCs), both registered and bearer. As these new saving instruments are not very different from the KDCs, the holding of SSCs is considered as a continuation of KDCs.

Corresponding to the Divisia index is a price index-the price dual. The Divisia index of prices is obtained by cumulating over time a weighted sum of the rates of change of the component prices, where the weights are the shares of the component assets in the total expenditure on all assets in the index. The same price and quantity data as are used to construct the Divisia monetary index are used to construct the Divisia price index. 


$$
\ln P_{t}-\ln P_{t-1}=\sum w_{i t}\left(\ln p_{i t}-\ln p_{i t-1}\right)
$$

where:

$P_{t}=$ Price dual to the Divisia quantity index, i.e., Divisia price index.

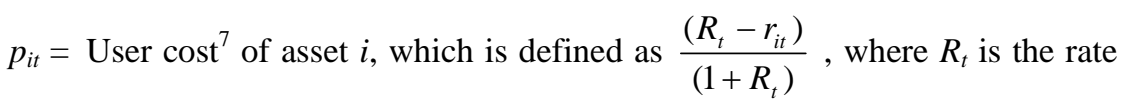
of return on benchmark asset and $r_{i t}$ is the current period yield on the asset $i$.

$$
\begin{aligned}
w_{i t} & =\frac{1}{2}\left(s_{i t}+s_{i t-1}\right) \\
S_{i t} & =\frac{p_{i t} m_{i t}}{\sum_{i}\left(p_{i t} m_{i t}\right)}
\end{aligned}
$$

The end period consumer price index (CPI) $(1980-81=100)$ is used to deflate money balances and to proxy the price movements. It includes the consumption of imports while excluding exports and covers a broad consumption expenditure. The data for the CPI is taken from various issues of the SBP publications, i.e., the SBP's Annual Report and Quarterly Bulletin.

Data on gross national product (GNP) on an annual basis are obtained from various issues of the SBP Annual Report. Since these data are not available on a quarterly basis, we construct the quarterly series of GNP by an interpolation procedure used by Khan and Raza (1989).

\section{COINTEGRATION ANALYSIS AND LONG-RUN DEMAND FOR MONEY}

Following Johansen (1988) and Johansen and Juselius (1990), we estimate a $\mathrm{VAR}^{8}$ consisting of three variables $\ln M{ }^{9} \ln Y$, and $\operatorname{lnOC}^{10}$ for each monetary aggregate, viz., simple-sum and Divisia M1 and M2 respectively. Five lags were included for each variable to ensure that the error term ' $\varepsilon_{t}$ ' is white noise. On the

${ }^{7}$ See, for example, Barnett (1978).

${ }^{8}$ Since our data are seasonally unadjusted, we have also conducted the cointegration analysis by including the centred seasonal dummies advocated by Johansen and Juselius (1990) as I(0) variables. In all cases, LR statistics based on both maximal eigenvalue and trace of the stochastic matrix indicated the presence of only one cointegrating vector among the variables of the model. However, the weak exogeneity tests for the long-run parameters of the model suggested the absence of a significant and correctly signed error-correction mechanism in the money equations for both the Divisia and simple-sum M1. Hence, the cointegrating vectors and their corresponding weights can not be normalised with respect to these monetary aggregates and can not be termed as money demand functions.

${ }^{9}$ End-period CPI deflated measure of both simple-sum and Divisia quantity monetary aggregate.

${ }^{10}$ For simple-sum monetary aggregates, $\operatorname{lnOC}-\log (1+O C)$, where $O C$ is the differential between rate of return on the alternative asset and own rate of return of the particular aggregate. For Divisia measure, logarithm of the corresponding index of user cost is used as $\operatorname{lnOC}$. 
basis of the plots of the individual data series, a model with a linear trend in the nonstationary part of the process is assumed and ' $\mu$ ' is assumed to contain the effects both from the intercept and from the linear trend. The sample period from 1974Q41992Q4 containing 73 observations is used to determine any long-run relationship among the variables.

Table 1-a presents the results of cointegration analysis. In all cases, the cointegrating vectors and their corresponding weights were normalised with respect to monetary aggregates, viz., Divisia and simple-sum M2 and M1. For each of the monetary aggregates, the I(1) vector space is spanned by at least one cointegrating vector. The maximal eigenvalue statistic in all the cases is greater than the 95 percent critical value and hence rejects the null $\left(\mathrm{H}_{0}: \mathrm{r}=0\right)$ of no cointegration among the three variables of the model. The LR statistic for the null hypothesis $\mathrm{H}_{0}: \mathrm{r} \leq 1$ is less than the 95 percent critical values, and thus in all the cases the null hypothesis of one cointegrating vector against the alternative of two cointegrating vectors can not be rejected. It is therefore reasonable to conclude that there is only one cointegrating relationship between the variables of the model. The likelihood ratio test, based on the trace of the stochastic matrix, also reinforces the presence of only one cointegrating vector in all four cases. The cointegrating relationships for all four monetary aggregates (simple-sum and Divisia M1 and M2) are clearly interpretable as the money demand functions which are consistent with the theoretical priors that the demand for money is a positive function of real income (GNP) and a negative function of the opportunity cost variable.

The coefficient estimates ' $\beta$ ' of the cointegrating relations along with the corresponding adjustment coefficients ' $\alpha$ ' are reported in Tables I-b and 1-c. The ' $\alpha$ ' vectors indicate the rate of feedback of deviations from the long-run money demand relationship to the dynamic behaviour of the endogenous variables of the VAR. The estimated vectors clearly indicate that the main effect of the money demand cointegrating vector is through their feedback onto real money holdings. The direction and magnitude of the feedback is also consistent with a stable, errorcorrecting model of the demand for money. Since logarithmic data is used, the relevant coefficient of ' $\alpha$ ' vector indicates a feedback of approximately 37 percent and 40 percent per period for simple-sum M1 and M2 respectively. The feedback in the case of Divisia M1 and M2 is approximately 39 percent and 48 percent respectively. In common with a number of studies, the long-run income elasticity is found to be greater than unity in all the four money demand specifications.

There are two possible reasons for this. The greater than unit elasticity implies a declining velocity with income. A downward trend in velocity is consistent with the increased process of monetisation. This process is made up of the decline of nonmonetary payments as markets develop and the spread of the commercial banking system supplying the public with notes and deposits. ${ }^{11}$ A developing economy such

\footnotetext{
${ }^{11}$ See Bordo and Jonung (1981) for the development of this argument.
} 
Table 1

Cointegration Analysis*

Sample-1974Q4 - 1992Q4, VAR=5

a. LR Tests to Determine the Rank of $\Pi$

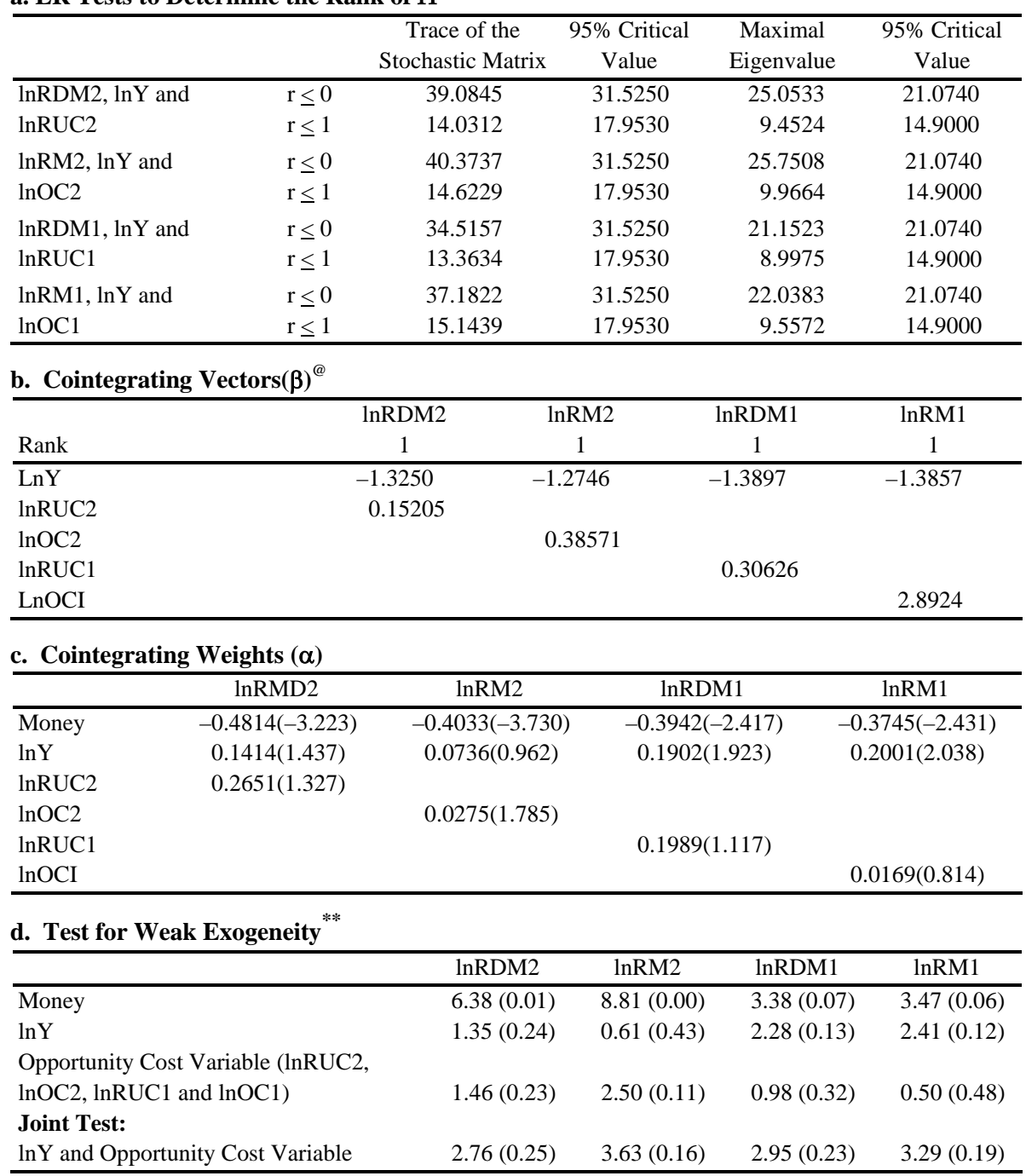

Notes: $t$-values in parenthesis.

${ }^{*}$ Both the ML-estimates for $\beta^{\prime}$ and the likelihood ratio statistics $\left(\mathrm{LR}_{1}\right.$ and $\left.\mathrm{LR}_{2}\right)$ have been computed with MICROFIT 3.0 [Pesaran and Pesaran (1991)].

** Tests of weak exogeneity are conducted using the programme 'CATS in RATS' written by Hansen and Juselius (1995).

$@$ Normalised on money. 
as Pakistan is still in the process of monetisation. The second possibility is that the unrecorded or 'black' economy is expanding faster than the recorded economy, resulting in a downward trend in income velocity. ${ }^{12}$ Since the demand for money is positively related to total income, the greater than unit elasticity is consistent with the measurement error in real income. ${ }^{13}$

Table 1-d reports the results of weak exogeneity tests for the long-run parameters of the models. Weak exogeneity with respect to the long-run parameters of the VAR is tested by Johansen's likelihood ratio test by imposing zero restrictions on the cointegrating weights. An important result is the rejection of the null of a zero cointegrating weight for Divisia and simple-sum M2 at 5 percent significance level and Divisia and simple-sum M1 at 10 percent level. The existence of a significant and correctly signed error-correction mechanism in the money equations supports the normalisation imposed on the system and the interpretation of these equations as money demand functions. The cointegrating weights for real GNP and opportunity cost variables in all the cases are found to be statistically insignificant. These results rule out the possibility of conditioning any of the other variables on the monetary aggregates. The weak exogeneity of the income and opportunity cost variables also suggests the possibility of efficient single-equation estimation of the long-run parameters of demand for real money.

\section{DYNAMIC DEMAND FOR MONEY FUNCTIONS FOR PAKISTAN}

We estimate a series of dynamic error-correction models for each monetary aggregate based on the cointegrating vectors reported in the preceding section. Since the real GNP and opportunity cost variables are found to be weakly exogenous in all cases, we estimate the following unrestricted quarterly money demand function for each monetary aggregate:

$$
\Delta \ln M_{t}=\mu+\sum_{i=1}^{4} \phi_{i} \Delta \ln M_{t-i}+\sum_{i=0}^{4} \delta_{i} \Delta \ln Y_{t-i}+\sum_{i=0}^{4} \gamma_{i} \Delta \ln O C_{t-i}+\psi E C M+\varepsilon_{t}
$$

where, $\quad M=$ Various measures of real money balances, i.e., Divisia and simplesum M2 and M1 deflated by end-period CPI.

$Y=$ Real GNP (Nominal GNP deflated by end-period CPI).

$O C=$ Opportunity cost variables, i.e., RUC2, RUC1, OC2, and OCI.

$E C M=\beta^{\prime} \mathrm{X}_{t-5}$.

Following the general specific procedure [Hendry et al. (1984)], the variables with non-significant coefficients were dropped and the final real money demand equations for all the aggregates are given in Table 2.

\footnotetext{
${ }^{12}$ See Feige (1989) for an example of this argument.

${ }^{13}$ See also Matthews and Rastogi (1985) for a development of this argument.
} 
Table 2

Estimates of Real Money Demand

\begin{tabular}{|c|c|c|c|c|}
\hline & $\Delta \operatorname{lnRDM} 2$ & $\Delta \operatorname{lnRM} 2$ & $\Delta \operatorname{lnRDM} 1$ & $\Delta \operatorname{lnRM} 1$ \\
\hline Constant & -5.2362 & -1.6185 & -4.9007 & -1.8577 \\
\hline$\Delta \ln \mathrm{M}_{\mathrm{t}-1}$ & -0.4430 & -0.4944 & -0.4314 & -0.4149 \\
\hline$\Delta \ln \mathrm{M}_{\mathrm{t}-2}$ & -0.3460 & -0.3902 & -0.2993 & -0.2805 \\
\hline$\Delta \ln \mathrm{M}_{\mathrm{t}-3}$ & -0.5001 & -0.5339 & -0.4619 & -0.3779 \\
\hline$\Delta \ln Y_{\mathrm{t}}$ & +0.8084 & +0.8031 & +0.8689 & +0.8388 \\
\hline$\Delta \ln \mathrm{Y}_{\mathrm{t}-1}$ & +0.7188 & +0.7922 & +0.7145 & +0.7035 \\
\hline$\Delta \ln \mathrm{Y}_{\mathrm{t}-2}$ & +0.5034 & +0.5921 & +0.5041 & +0.5870 \\
\hline$\Delta \ln \mathrm{Y}_{\mathrm{t}-3}$ & +0.6661 & +0.8302 & +0.6145 & +0.6504 \\
\hline$\Delta \ln Y_{t-4}$ & +0.6530 & +0.6487 & +0.6918 & +0.6498 \\
\hline$\Delta \operatorname{lnOC} \mathrm{C}_{\mathrm{t}-1}$ & -0.1781 & & -0.2868 & -2.5269 \\
\hline ECM & -0.5714 & -0.5742 & -0.4961 & -0.4574 \\
\hline $\bar{R}^{2}$ & 0.8539 & 0.8414 & 0.8389 & 0.8381 \\
\hline$F(10,57)$ & 40.1597 & 40.4820 & 35.8942 & 36.6737 \\
\hline DW & 2.1941 & 1.8812 & 2.2337 & 2.2444 \\
\hline Se & 0.0246 & 0.0232 & 0.0265 & 0.0249 \\
\hline \multicolumn{5}{|l|}{ Serial Correlation } \\
\hline$F(1,56)$ & $0.9717(.328)$ & $0.3262(.570)$ & $1.6777(.201)$ & $1.8609(.178)$ \\
\hline$F(4,53)$ & $1.0047(.413)$ & $1.2657(.295)$ & $1.4008(.246)$ & $1.1528(.342)$ \\
\hline$F(8,49)$ & $0.5375(.822)$ & $1.0008(.447)$ & $0.7175(.675)$ & $0.6319(.747)$ \\
\hline ARCH: F(1, 56) & $1.1447(.289)$ & $4.6098(.036)$ & $0.7123(.402)$ & $0.9919(.324)$ \\
\hline$F(4,53)$ & $0.7360(.572)$ & $2.0629(.098)$ & $0.4890(.744)$ & $0.4534(.769)$ \\
\hline $\begin{array}{l}\text { Functional Form } \\
\qquad \mathrm{F}(1,56)\end{array}$ & 0.0131 (.909) & $0.0660(.798)$ & $0.1284(.721)$ & $0.7190(.400)$ \\
\hline Normality: $\quad \chi^{2}(2)$ & $2.2391[.326]$ & $2.2788[.320]$ & $2.9560[.228]$ & $2.7883[.248]$ \\
\hline $\begin{array}{l}\text { Heteroscedasticity: } \\
\mathrm{F}(1,66)\end{array}$ & $0.3490(.557)$ & $1.6257(.207)$ & $0.0489(.826)$ & $0.0021(.963)$ \\
\hline \multicolumn{5}{|c|}{ Parameter Constancy Over: 1988Q3-1992Q4 } \\
\hline Pred. Failure: F(18, 39) & $1.0618(.422)$ & $1.3020(.238)$ & $0.9734(.507)$ & $0.9818(.498)$ \\
\hline Chow Test: F(11, 46) & $1.0336(.434)$ & $1.5247(.160)$ & $0.9791(.479)$ & $1.0686(.406)$ \\
\hline \multicolumn{5}{|c|}{ Parameter Constancy Over: 1990Q3-1992Q4 } \\
\hline Pred. Failure: F(10, 47) & $1.5580(.149)$ & $2.0290(.051)$ & 1.0974(.384) & $0.9825(.471)$ \\
\hline Estimation Period: 1976 & $-1992 Q 4$ & & & \\
\hline
\end{tabular}


The statistical characteristics of the dynamic equations satisfy conventional requirements. The residuals of the estimated money demand equations for all the aggregates appear to be normally ${ }^{14}$ and homoscedastically distributed and exhibit no significant first- or higher-order autocorrelation. To test for a non-linear functional form, Ramsey's (1969) RESET test is used to test for a non-linear functional form which examines the effect of adding the square of fitted values of the dependent variable in the extended regression. The RESET statistic in all cases leads to the acceptance of the hypothesis of correct functional form. The parameter constancy is evaluated over two different periods using the F-version of Chow's (1960) predictive failure test and Chow test (test of the stability of the regression coefficients).

The macro-economic and structural adjustment programme in Pakistan (of which the financial sector reforms are a major part) was first initiated in the financial year 1988-89, so we check the parameter constancy over the period 1988Q31992Q4. However, since these reforms were vigorously pursued as from the beginning of 1990, we also check the parameter constancy over the period 1990Q31992Q4. The predictive failure and Chow statistics for the period 1988Q3-1992Q4 indicate that the null hypothesis of parameter constancy cannot be rejected over the period at 5 percent level. The predictive failure test statistics for the period 1990Q31992Q4 also show parameter stability over the period. In terms of goodness-of-fit, the regressions for all the monetary aggregates show high adjusted R-square.

\section{CONCLUSION}

We have estimated the demand for money functions for different monetary aggregates, viz., Divisia and simple-sum M2 and M1 for the period 1974Q41992Q4, using cointegration tests (Johansen procedure) and error correction modelling. Though we used the interpolated series for GNP, all the estimated equations are fully consistent with the theoretical priors from the literature on the demand for money. In all the specifications, the long-run income elasticity of money is found to be greater than unity which suggest that the most commonly accepted restriction of unitary or less than unitary income elasticity of money employed in the money demand literature is inconsistent with the data for Pakistan. The weak exogeneity of real income and opportunity cost variables with respect to the long-run parameters suggest the possibility of efficient single-equation estimation of the longrun parameters of demand for real balances. However, efficient single-equation estimation of the short-run dynamics of money demand is doubtful for all the specifications because of the presence of Granger Causality from money to income, implying that income is not strongly exogenous (results not reported).

\footnotetext{
${ }^{14}$ The assumption of normality of the residuals is tested by using the Bera and Jarque (1981) test which uses the first four moments of distribution to test whether the skewness and excess kurtosis is the same as that produced by the standard normal distribution.
} 
The statistical characteristics of the short-run dynamic money demand functions using different monetary aggregates, viz., Divisia and simple-sum M2 and M1, are found to be uniformly good. The policy significance of our results is limited and currently there is no advantage from switching from simple-sum to Divisia aggregates at the existing level of official aggregation as the proper indicators of monetary policy. As Laidler (1997) has argued, institutional change, whether driven by technology or regulation, will alter the relative 'moneyness' of monetary assets, and the use of the Divisia index to represent monetary aggregates captures these effects in a way that simple sum does not. Since Pakistan is currently pursuing a policy of financial deregulation which undoubtedly will lead to more competition and financial innovation in the financial industry, the Divisia aggregates may in future prove to be the better indicators of the conduct of monetary policy because they provide a framework for dealing with the effects of financial innovations and also perform better at high level of aggregation.

\section{REFERENCES}

Abe, S., M. J. Fry, B. K. Min, P. Vongvipanond, and T. P. Yu (1975) The Demand for Money in Pakistan: Some Alternative Estimates. The Pakistan Development Review 14:2 249-257.

Aghevli, B. B., M. S. Khan, P. R. Narvekar, and B. K. Short (1979) Monetary Policy in Selected Asian Countries. IMF Staff Papers 26:4 775-824.

Ahmad, M., and A. H. Khan (1990) A Re-examination of the Stability of the Demand for Money in Pakistan. Journal of Macroeconomics 12:2 307-21.

Akhtar, M. A. (1974) The Demand for Money in Pakistan. The Pakistan Development Review 13:1 40-54.

Barnett, W. A. (1978) The User Cost of Money. Economics Letters 1: 145-149.

Barnett, W. A. (1980) Economic Monetary Aggregates: An Application of Index Number and Aggregation Theory. Journal of Econometrics 14: 11-48.

Barnett, W. A., and P. A. Spindt (1979) The Velocity Behaviour and Information Content of Divisia Monetary Aggregates. Economics Letters 4: 51-57.

Barnett, W. A., E. K. Offenbacher, and P. A. Spindt (1984) The New Divisia Monetary Aggregates. Journal of Political Economy 92:6 1049-1085.

Bera, A. K., and C. M. Jarque (1981) An Efficient Large-sample Test for Normality of Observations and Regression Residuals. Australian National University, Canberra. (Working Papers in Econometrics No. 40.)

Bordo, D. M., and L. Jonung (1981) The Long-run Behaviour of the Income Velocity of Money in Five Advanced Countries, 1870-1975: An Institutional Approach. Economic Inquiry 19: 96-116.

Boswijk, H. P. (1990) On the Scope of Conditional Dynamic Modelling of Cointegrated Variables. Tinbergen Institute Research Bulletin 2: 97-111.

Chow, G. C. (1960) Tests of Equality between Sets of Coefficients in Two Linear 
Regressions. Econometrica 28: 591-605.

Dickey, D. A., D. W. Jansen, and D. L. Thornton (1991) A Primer on Cointegration with an Application to Money and Income. Review of the Federal Reserve Bank of St. Louis, March/April, 58-78.

Engle, Robert F., and C. W. J. Granger (1987) Co-integration and Error Correction: Representation, Estimation, and Testing. Econometrica 55: 251-76.

Engle, Robert F., D. F. Hendry, and J. F. Richard (1983) Exogeneity. Econometrica 51:2 277-304.

Ericsson, N. R., J. Campos, and H. A. Tran (1990) PCGIVE and David Hendry's Econometric Methodology. Revista de Econometria 10: 1-136.

Feige, E. L. (1989) The Meaning and Measurement of the Underground Economy. In E. L. Feige (ed) The Underground Economies. Cambridge: Cambridge University Press.

Goldfeld, S. M. (1973) The Demand for Money Revisited. Brooking's Papers on Economic Activity, March, 577-638.

Hansen, H., and K. Juselius (1995) CATS in RATS: Cointegration Analysis of Time Series. Manual. Illinoise: Estima.

Hendry, D. F., A. R. Pagan, and J. D. Sargan (1984) Dynamic Specification. In Z. Griliches and M. D. Intriligator (eds) Handbook of Econometrics. 2: Amsterdam: North-Holland.

Hendry, D. F., and G. E. Mizon (1993) Evaluating Dynamic Econometric Models by Encompassing the VAR. In P. C. B. Phillips and V. B. Hall (eds) Models, Methods, and Applications of Econometrics. Essays in Honour of Rex Bergstrom. Oxford: Basil Blackwell. 272-300.

Johansen, S. (1988) Statistical Analysis of Cointegration Vectors. Journal of Economic Dynamics and Control 12: 231-54.

Johansen, S. (1992) Testing Weak Exogeneity and the Order of Cointegration in UK Money Demand Data. Journal of Policy Modelling 14:3 313-34.

Johansen, S., and K. Juselius (1990) Maximum Likelihood Estimation and Inference on Cointegration - with Applications to Demand for Money. Oxford Bulletin of Economics and Statistics 52: 169-210.

Johansen, S., and K. Juselius (1992) Some Structural Hypothesis in a Multivariate Cointegration Analysis of the Purchasing Power Parity and the Uncovered Interest Parity for the UK. Journal of Econometrics 53: 211-44.

Khan, A. H. (1980) The Demand for Money in Pakistan: Some Further Results. The Pakistan Development Review 19:1 25-49.

Khan, A. H. (1981), The Demand for Money in Pakistan: A Disaggregated Analysis. Pakistan Institute of Development Economics, Islamabad. (Research Report Series No. 114.)

Khan, A. H. (1982) Permanent Income, Inflation Expectations, and the Money Demand Function in Developing Countries. The Pakistan Development Review 
21:4 259-273.

Khan, A. H. (1982a) The Demand for Money and the Variability of the Rate of Inflation: An Empirical Note. Economic Letters 10: 257-261.

Khan, A. H. (1982b) Adjustment Mechanism and the Money Demand Function in Pakistan. Pakistan Economic and Social Review 20:1 36-51.

Khan, A. H. (1982c) An Analysis of the Demand for Money in Pakistan. Journal of the Institute of Bankers in Pakistan 48:2 25-34.

Khan, A. H. (1994) Financial Liberalisation and the Demand for Money in Pakistan. The Pakistan Development Review 33:4 Part II, 997-1010.

Khan, A. H., and Bilquees Raza (1989) The Demand for Money in Pakistan: Quarterly Results 1972-1987. Pakistan Economic and Social Review 27:1 3348.

Khan, M. S. (1980) Monetary Shocks and the Dynamics of Inflation. IMF Staff Papers 27:2 250-285.

Laidler, D. (1997) Notes on the Microfoundations of Monetary Economics. Economic Journal 107:443 1213-1223.

Mangla, I. U. (1979) An Annual Money Demand Function for Pakistan: Some Further Results. The Pakistan Development Review 28:1 21-33.

Matthews, K., and A. Rastogi (1985) Little Mo and the Moonlighters: Another Look at the Black Economy. Quarterly Economic Bulletin, Liverpool Research Group in Macroeconomics 6:2 21-24.

Nisar, S., and N. Aslam (1983) The Demand for Money and the Term Structure of Interest Rates in Pakistan. The Pakistan Development Review 6:3 97-115.

Pasaran, M. H., and B. Pasaran (1991) MICROFIT 3.0: An Interactive Econometric Software Package User Manual. Oxford: Oxford University Press. xvi-277.

Ramsey, J. B. (1969) Tests for Specification Errors in Classical Linear Least Squares Regression Analysis. Journal of Royal Statistical Society B, 31: 350-71.

Sassanpour, C., and Moinuddin (1993) Experiments with Demand for Money Functions for Pakistan. State Bank of Pakistan Monthly Bulletin, May, i-xix.

Wong, C. (1977) Demand for Money in Developing Countries. Journal of Monetary Economics 3:1 59-86. 